\title{
Maturação in vitro de ovócitos de cães domésticos (Canis familiaris) em meio adicionado de polivinil-pirrolidona*
}

\author{
LUCILA CARBONEIRO DOS SANTOS
}

José Luiz Rodrigues (Orientador - UFRGS)

Banca: Lígia Pegoraro (EMBRAPA, Pelotas), Ricardo Azambuja (PUC-RS), Rui Fernando Félix Lopes (UFRGS)

Atualmente, os baixos índices de maturação nuclear ovocitária representam a maior limitação para o sucesso na produção in vitro de embriões caninos. O objetivo desse experimento foi determinar as taxas de maturação nuclear de ovócitos mantidos em meio TCM 199 suplementado com $4 \mathrm{mg} / \mathrm{mL}$ de polivil-pirrolidona (PVP) ou 10\% de soro de vaca em estro (SVE). Os ovários foram coletados de 21 cadelas saudáveis por ováriohisterectomia. As fêmeas se encontravam em vários estádios do ciclo estral no momento da remoção dos ovários. Os ovócitos foram selecionados e classificados subjetivamente de acordo com o seu aspecto morfológico e tamanho e em seguida, maturados por 48 horas a $37^{\circ} \mathrm{C}$, em atmosfera contendo $5 \%$ de $\mathrm{CO}_{2}$ em ar. Os ovócitos foram randomicamente distribuídos nos três grupos experimentais: (A) TCM 199 suplementado com $4 \mathrm{mg} / \mathrm{mL}$ de PVP + hST; (B) TCM 199 com 10\% de SVE + hST; (C) TCM 199 adicionado de SVE, estradiol + FSH + LH + hST (controle). Não foram observadas diferenças significativas nas taxas de metáfase II entre os tratamentos A $(4,7 \%, 8 / 170)$, B (3,52\%, 6/183) e C $(4,70 \%, 8 / 172)(\mathrm{P}>0,05)$. Em conclusão, o presente estudo demonstrou que a maturação nuclear in vitro de ovócitos caninos pode ser alcançada em meio TCM 199, suplementado somente com a polivinil-pirrolidona na mesma proporção que os ovócitos cultivados em meio suplementado com soro, gonadotrofinas e estradiol.

Descritores: maturação de ovócitos caninos, polivinil-pirrolidona, gonadotrofinas, estradiol, meio sem soro. 


\title{
In vitro nuclear maturation of bitch oocytes in presence of polyvinyl-pyrrolidone ${ }^{* *}$
}

\author{
LUCILA CARBONEIRO DOS SANTOS
}

\author{
José Luiz Rodrigues (Adviser - UFRGS)
}

Committee: Lígia Pegoraro (EMBRAPA, Pelotas), Ricardo Azambuja (PUC-RS), Rui Fernando Félix Lopes (UFRGS)

\begin{abstract}
At moment, the main limitation to successful produce dog embryos in vitro is the low oocyte maturation rate to the metaphase II stage. The objective of this experiment was to determine the rates of nuclear maturation of dog oocytes cultured in TCM 199 medium supplemented with $4 \mathrm{mg} / \mathrm{mL}$ polyvinyl-pirrolidone (PVP) or 10\% estrus cow serum (ECS). Ovaries were collected from 21 healthy bitches by ovariohysterectomy. Females were at various stages of the estrous cycle at the moment of ovary retrieval. The oocytes were selected and classified subjectively according to their morphology and size, and matured for 48 hours at $37^{\circ} \mathrm{C}$, in atmosphere of $5 \%$ of $\mathrm{CO}_{2}$ in air Oocytes were randomly distributed in three treatment groups: (A) TCM 199 supplemented with $4 \mathrm{mg} / \mathrm{mL}$ PVP + hST; (B) TCM 199 with $10 \% \mathrm{ECS}+\mathrm{hST}$; (C) TCM 199 supplemented with $10 \%$ ECS, oestradiol + FSH + LH + hST (control). There were not significant differences in metaphase II rates among treatments A $(4.7 \%, 8 / 170)$, B $(3.52 \%, 6 / 183)$ e C $(4.70 \%, 8 / 172),(\mathrm{P}>0.05)$. In conclusion, the present study demonstrated that in vitro nuclear maturation of domestic dog oocytes can be achieved in TCM 199 supplemented only with PVP at similar proportions that a medium added with serum, gonadotropins and estradiol.
\end{abstract}

Key words: canine oocyte maturation, PVP, gonadotropins, estradiol, serum-free media. 